\title{
Enhancing the Defensive Mechanism of Lead Affected Barley (Hordeum vulgare L.) Genotypes by Exogenously Applied Salicylic Acid
}

\author{
Taskeen Arshad ${ }^{1}$, Nazimah Maqbool ${ }^{1}$, Farrukh Javed ${ }^{1} \&$ Muhammad Usman Arshad $^{2}$ \\ ${ }^{1}$ Department of Botany, University of Agriculture, Faisalabad, Pakistan \\ ${ }^{2}$ Department of Plant Breeding and Genetics, University of Agriculture, Faisalabad, Pakistan \\ Correspondence: Nazimah Maqbool, Department of Botany, University of Agriculture, Faisalabad 38040, \\ Pakistan. Tel: 92-340-696-2897. E-mail: nazimahmaqbool@gmail.com
}

Received: November 13, 2016

Accepted: December 20, 2016

Online Published: January 15, 2017

doi:10.5539/jas.v9n2p139

URL: http://dx.doi.org/10.5539/jas.v9n2p139

\begin{abstract}
Lead is a non-essential element reduced plant growth and development that may cause multifarious disturbance in physiological, biochemical and structural integrity of plants. SA is an efficient signal molecule induces systemic resistance responses that control local defense reactions in plants. To evaluate the effect of SA on photosynthetic activity of $\mathrm{Pb}$ affected plants therefore a pot experiment was conducted on barley genotype Juo93 and Juo- 87 in the Old Botanical Garden, University Of Agriculture, Faisalabad, Pakistan. Three treatment levels $(0,100$ and $200 \mu \mathrm{M})$ of lead sulphate $\left(\mathrm{PbSO}_{4}\right)$ were applied in thrice replication with or without SA $(0.5$ $\mathrm{mM}$ ) along half strength of Hoagland's solution till the termination of experiment. The experiment was arranged in a completely randomized design. During course of study growth and pigments modulations were recorded. The result indicated that growth parameters such as root and shoot length, leaf area, fresh weight of shoot and root, dry weight of shoot and root were reduced under lead toxicity. $\mathrm{Pb}$ stress damaged the photosynthetic pigments such as Chlorophyll a, chlorophyll b, total chlorophyll and carotenoids but chlorophyll a/b was increased under $\mathrm{Pb}$ stress whereas exogenous application of SA alleviated the negative effect of lead toxicity. Juo- 93 showed more tolerance to $\mathrm{Pb}$ toxicity as compared to Juo-87.
\end{abstract}

Keywords: carotenoid, lead toxicity, barley, chlorophyll, salicylic acid

\section{Introduction}

Heavy metal stress is one of the major abiotic stresses that cause environmental pollution in recent decades (Gisbert et al., 2003; Castro et al., 2011). These metals unlike other organic pollutants are not degraded and converted into harmless compounds via biological processes. Elevated concentrations of both essential and non-essential heavy metals in the soil can lead to toxicity symptoms and growth inhibition in most plants (Hall, 2002; Li et al., 2010). Toxicity may result from the binding of metals to sulphydryl groups in proteins, leading to inhibition of activity or disruption of structure, or from displacement of an essential element (Capuana, 2011). Heavy metals effects chlorophyll content in plants by interfering with chlorophyll synthesis either through direct inhibition of an enzymatic step or by inducing deficiency of an essential nutrient (Meers et al., 2010). Lead is very toxic environmental pollutant which is widely distributed in the soil and contaminated water. The key enzyme for chlorophyll biosynthesis i.e. $\alpha$-amino laevulinate dehydrogenase is strongly inhibited by $\mathrm{Pb}$ ions $(\mathrm{D}$. D. K. Prasad \& A. R. K. Prasad, 1987). Photosynthesis is especially affected by lead exposure (Bazzaz et al., 1975); chlorophyll and carotenoids contents, photosynthetic rate and $\mathrm{CO}_{2}$ assimilation are strongly decreased (Eun et al., 2002).

Seed treatment or foliar application of chemicals like glycinebetaine, kinetin, salicylic acid (Gunes, 2007; Karlidag, 2009) may increase yield of different crops due to reduction in stress induced inhibition of plant growth (Khan et al., 2003; Elwana \& El-Hamahmyb, 2009). Salicylic acid is an endogenous growth regulator of phenolic nature and acts as potential non-enzymatic antioxidant which participates in the regulation of many physiological processes in plants (Simaei et al., 2012; Horvath et al., 2007), such as stomatal closure, photosynthesis, ion uptake, inhibition of ethylene biosynthesis, transpiration and stress tolerance (Khan et al., 2003; Arfan et al., 2007). Chlorophyll and carotenoid contents of maize leaves were increased upon treatment 
with SA under lead stress (Bosch et al., 2007; Najafian et al., 2009). Barley (Hordeum vulgare L.) is a highly adaptable cereal grain and considered to be the most drought and salinity tolerant among cereals (Ceccarelli et al., 1987; Belaid \& Morris, 1991).

The aim of this project is to explore the response of barley under $\mathrm{Pb}$ contamination and ameliorating potential of SA towards metal toxicity.

\section{Materials and Method}

Seeds of two barley genotypes Juo-93 and Juo-87 were obtained from Ayub Agriculture Research Institute (AARI), Faisalabad, Pakistan. Ten seeds of good vigor of both genotypes were graded and sown in sand filled (5 $\mathrm{kg})$ plastic pots $(30 \times 20 \mathrm{~cm}$ size $)$. The pots were kept in a net house under bright sunlight. The climatic conditions were $30 \pm 2{ }^{\circ} \mathrm{C}$ with $50 \%$ relative humidity at the time of experiment. Lead sulphate $\left(\mathrm{PbSO}_{4}\right)$ of 100 and $200 \mu \mathrm{M}$ along with $0.5 \mathrm{mM}$ SA was applied by mixing with Hoagland's solution till the termination of experiment. Control was without treatment of $\mathrm{SA}$ and $\mathrm{Pb}$ for both barley genotypes for comparison. After 58 days of germination, prior to uprooting of plants, the intact plants were measured for shoot length and leaf area. Leaves of Juo-93 and Juo-87 varieties for each treatment was sampled and stored in an ice bath, immediately brought in to the $\mathrm{Lab}$ and grinded in $80 \%$ acetone for the estimation of photosynthetic pigments following spectrophotometric method (Hitachi-U-2001, Japan) (Yoshida et al., 1976; Davies, 1976). Plants were uprooted from three replicates for the measurement of root length, shoot and root fresh weight. For dry weight determination, the shoot and root parts were properly washed with water, blotted dry, wrapped in labelled paper bags and kept in an oven at $70{ }^{\circ} \mathrm{C}$ for one week.

The three factors factorial experiment was arranged in a completely randomized way. The collected data was statistically analyzed using LSD Test and their means were compared applying DMRT comparison Test.

\section{Results}

Genotypes Juo-93 and Juo-87 showed significant $(\mathrm{P}<0.05)$ differences for growth attributes under $\mathrm{SA}$ and $\mathrm{Pb}$ treatments. Juo-93 performed better than Juo-87 under high concentration of $\mathrm{Pb}$. Salicylic acid (SA) application was found beneficial for the growth of both barley genotypes. Length as well as fresh and dry weights of shoot and root was enhanced by SA as compared to control. Juo-93 showed great shoot and root length, their fresh weights as compared to Juo-87 in control. Rooting medium application of SA enhanced length and fresh weights of both upper and lower parts of both genotypes. Pb level of $100 \mu \mathrm{M}$ was less toxic for shoot length and fresh weights whereas $200 \mu \mathrm{M} \mathrm{Pb}$ was more damaging for root length and fresh weights. Although SA application in combination with $\mathrm{Pb}(100 \mu \mathrm{M}$ and $200 \mu \mathrm{M})$ treated plants improved the growth of both genotypes. Similar response in shoot and root dry weights were observed in the presence of SA and $\mathrm{Pb}$ treatments as shown by other growth parameters (Figure 1). 


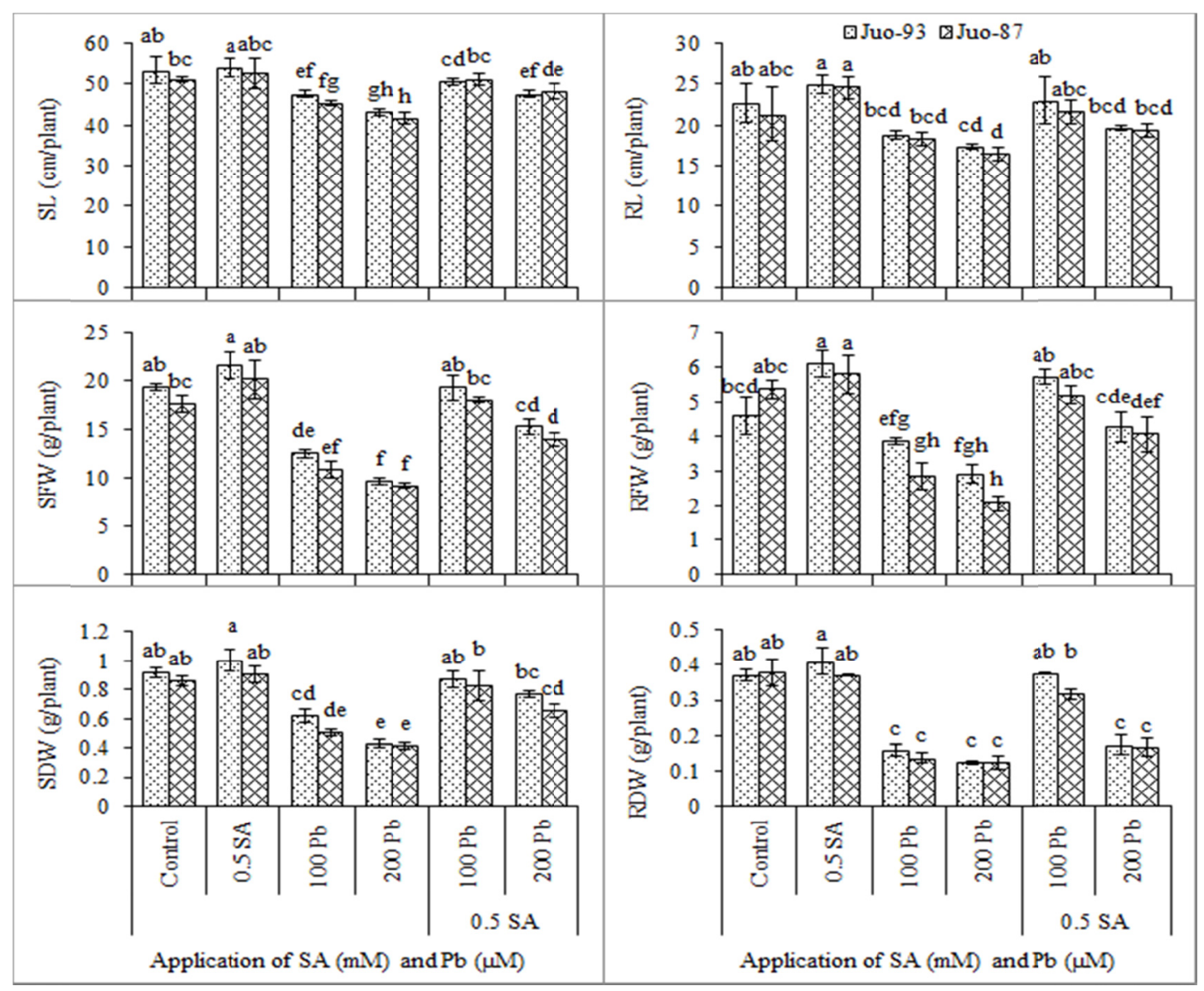

Figure 1. Graphical presentation of growth attributes of two barley genotypes (Juo-97 and Juo-87) treated with $\mathrm{SA}(0.5 \mathrm{mM})$ and $\mathrm{Pb}(100$ and $200 \mu \mathrm{M})$

Note. $\mathrm{SL}=$ shoot length, $\mathrm{RL}=$ root length, $\mathrm{SFW}, \mathrm{SDW}=$ shoot fresh and dry weights, $\mathrm{RFW}, \mathrm{RDW}=$ root fresh and dry weights. Histogram and Error bars represent Means \pm SD, while labels represent significance levels of treatments and genotypes $(\mathrm{P}<0.05)$.

Juo-93 was found to be more efficient photosynthetically as compared to Juo-87 in control as well as treatment applications. SA broaden the leaf area in barley genotypes directly provide more surface area for photosynthetic activity. The chlorophyll and carotenoids contents increased in both by the increment of $\mathrm{SA}$. $\mathrm{Pb}$ was proved to be toxic and directly affect the concentration of photosynthetic pigments in barley. Plants treated with $200 \mu \mathrm{M} \mathrm{Pb}$ had less chl-a, chl-b, chl-T in Juo-93 and Juo-87 as compared to $100 \mu \mathrm{M} \mathrm{Pb}$. Application of SA in combination with both the treatments of $\mathrm{Pb}(100,200 \mu \mathrm{M})$ enhanced the amount of chl-a, chl-b, chl-T and carotenoids, more in Juo-97 in comparison to Juo-87. Chl a/b ratio depicted that chl-a was more in both barley genotypes as compared to chl-b which shows that chl-b is more sensitive to $\mathrm{Pb}$ as compared chl-a (Figure 2). 


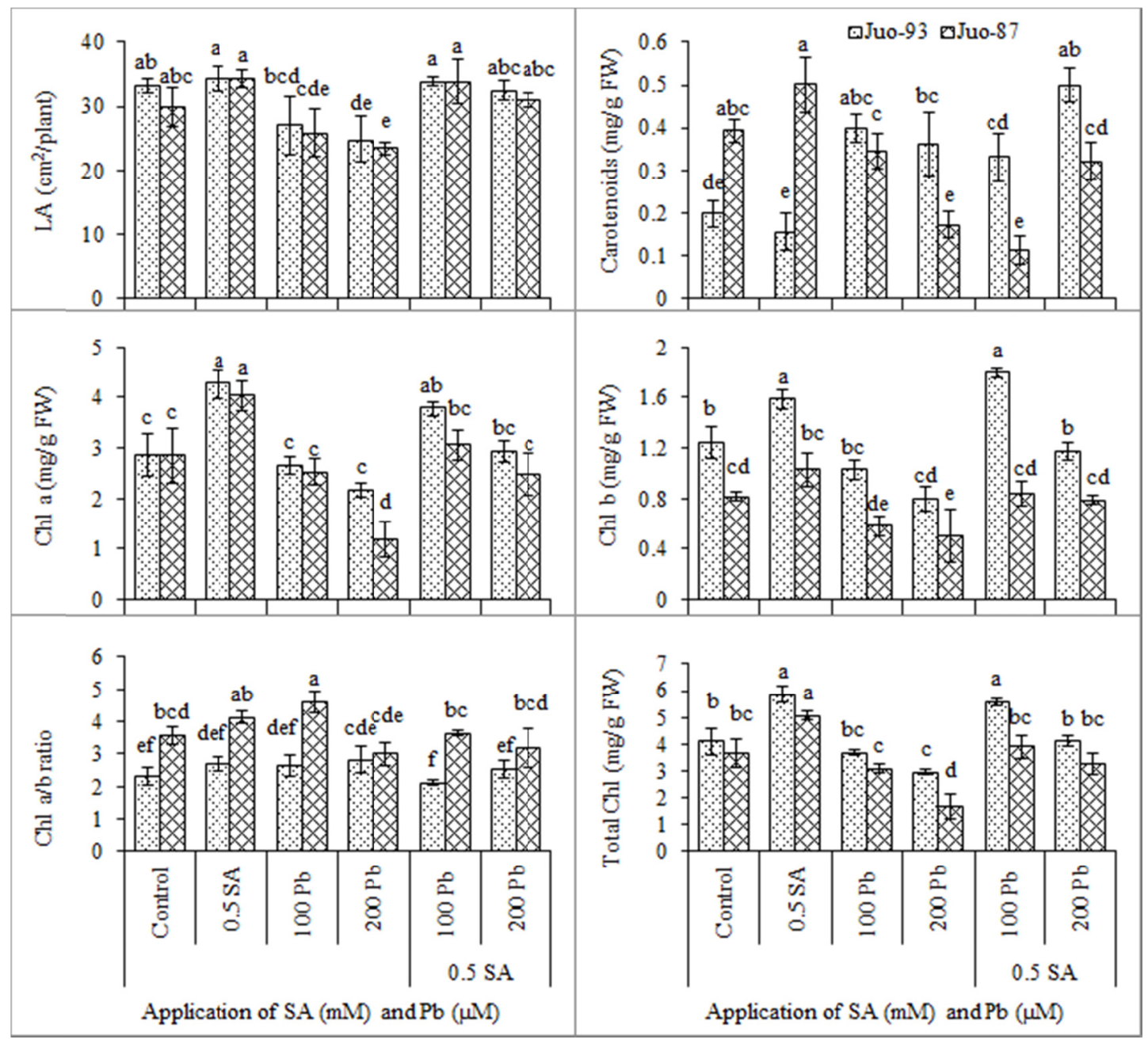

Figure 2. Graphical presentation of photosynthetic pigments of two barley genotypes (Juo-97 and Juo-87) treated with $\mathrm{SA}(0.5 \mathrm{mM})$ and $\mathrm{Pb}(100$ and $200 \mu \mathrm{M})$

Note. $\mathrm{LA}=$ leaf area, $\mathrm{Chl} \mathrm{a}=$ Chlorophyll $\mathrm{a}, \mathrm{Chl} \mathrm{b}=$ Chlorophyll $\mathrm{b}$. Histogram and Error bars represent Means $\pm \mathrm{SD}$, while labels represent significance levels of treatments and genotypes $(\mathrm{P}<0.05)$.

\section{Discussion}

Lead $(\mathrm{Pb})$ concentration increases in cultivated soils due to irrigation with sewage effluents. The other major cause is the use of lead arsenate in pesticides (Paivoke, 2002). The exhausting of $\mathrm{Pb}$ from automobiles and industrial emissions pollutes atmosphere for plants as well as humans (Awofolu, 2004). $\mathrm{Pb}$ is non-essential heavy metal that sharply decreases crop productivity (Sengar et al., 2008). Pb is considered as protoplasmic poison which is taken up by plants from soil and compartmentalized in vacuolar sequestration by phytochelatins (Anjum et al., 2015; Sharma et al., 2016). The entry of Pb from leaves is dependent on leaf morphology and their ability to absorb $\mathrm{Pb}$ from the aerial sources (Sharma \& Dubey, 2005) however, bulk of the $\mathrm{Pb}$ is taken up by plants from the soil through roots (Fahr et al., 2013). The translocation of $\mathrm{Pb}$ is highly restricted to upper parts of the plants through roots (Aziz et al., 2007; Tangahu et al., 2011). Calcareous or soil rich in phosphate precipitates $\mathrm{Pb}$ and make it non-toxic to plants ( $\mathrm{Li}$ et al., 2013). Application of $\mathrm{Pb}$ decrease the shoot and root length of two barley genotypes as studied in Brassica (Pallavi \& Rama, 2005; Ghani et al., 2016). Growth data result showed that 100 $\mu \mathrm{M}$ and $200 \mu \mathrm{M}$ level of lead reduced the shoot and root length, their fresh and dry weight and leaf area per plant (Hussain et al., 2013). Reduction in the root biomass has also been reported in turnip and lettuce when treated with lead (Hassanein et al., 2013; Gupta \& Sinha, 2007). Dry mass production of plant was dependant completely on light harvesting that was required for the generation of reducing powers (ATP and NADPH) during the photosynthesis light reaction and reducing powers use in dark reaction for photo-assimilate production (Taiz \& Zeiger, 2010). 
In present study, $200 \mu \mathrm{M}$ level of lead was found toxic for both barley genotypes while applied level of SA ( 0.5 $\mathrm{mM}$ ) in the rooting medium was effective in improving all the above mentioned growth parameters that were slightly affected by $\mathrm{Pb}$-stress. Important indication of stress tolerance in plants was prolific system of roots by increasing cell division of root apical meristems (Yang et al., 2000; Shakirova et al., 2003; Vicente \& Plasencia, 2011). SA application under Pb-stress enhanced the dry weight of root although relatively better in barley genotype Juo-93.

$\mathrm{Pb}$ application was toxic for photosynthetic attributes such as chlorophyll a and $\mathrm{b}$, total chlorophyll, carotenoids, but application of SA enhanced the contents of these pigments. Juo-93 showed less reduction in chlorophyll a, b, total chlorophyll and carotenoids contents under $\mathrm{Pb}$-stressed conditions and reduced ratio of Chlorophyll $\mathrm{a} / \mathrm{b}$ was also observed in this genotype than Juo-87. Key determinant of final productivity was maintenance of photosynthetic pigments under stressful circumstances (Wahid et al., 2009). Carotenoids not only harvest light on photosystems but acts as antioxidant mainly protecting photosystems from the action of ROS generated in chloroplast (de Passcale et al., 2001; Huchzermeyer \& Koyro, 2005). Chlorophyll ratio that is used as stress indicator enhanced with increase in heavy metal treatment (Monni et al., 2001). Improvement in chlorophylls ratio under environmental stress has been reported in leaves of spinach (Delfine et al., 1993). Under Pb stress rooting medium application of SA improved the contents of chlorophyll pigments, especially Chl-a, b and total chlorophylls (Khodary, 2004). Exogenous SA of $0.5 \mathrm{mM}$ concentration is beneficial in improving growth and protecting photosynthetic pigments from salts toxicity as in barley (Metwally et al., 2003; Ananieva et al., 2004).

$\mathrm{SA}$ application increased the antioxidation capacity and protection of photosynthetic apparatus against $\mathrm{Pb}$ stress. $\mathrm{Pb}$ translocation through roots mainly follow apoplastic pathway. Roots tend to hinder the movement of $\mathrm{Pb}$ in apoplast by binding it with carboxyl groups of carbohydrates galacturonic acid and glucuronic acid in the cell wall (Sharma \& Dubey, 2006). Pb transport from the soil to the root cells possibly through voltage gated Ca-channels of plasma membrane isolated from roots of wheat and corn plants (Marshall et al., 1994; Huang et al., 1994). This voltage gated $\mathrm{Pb}$ transport was blocked by nifidipine (a Ca-channel blocker) (Tomsig \& Suszkiw, 1991). Exogenous SA might be involves in activation of nifedipine, blocking the Ca-channels for $\mathrm{Pb}$ translocation into the roots. SA resulted in improved growth of two barley genotypes by restricting the $\mathrm{Pb}$ at root levels.

\section{Conclusion}

In conclusion, $\mathrm{SA}(0.5 \mathrm{mM})$ is found to be beneficial in enhancing $\mathrm{Pb}$ tolerance in two barley genotypes. Juo-93 showed better growth than Juo-87 under lead and salicylic acid treatments. Anatomical, molecular and genomic studies of $\mathrm{SA}$ and $\mathrm{Pb}$ treated roots should be done in order to understand the tolerance mechanism and selected level of SA $(0.5 \mathrm{mM})$ should be tested in field trails so that it can be recommended for metal toxic soils.

\section{References}

Ananieva, A. E., Christov, K. N., \& Popova, L. P. (2004). Exogenous treatment with salicylic acid leads to increased antioxidant capacity of barley plants exposed to paraquat. Journal of Plant Physiology, 161, 319-328. https://doi.org/10.1078/0176-1617-01022

Anjum, N. A., Hasanuzzaman, M., Hossain, M. A., Thangavel, P., Roychoudhury, A., Gill, S. S., \& Ahmad, I. (2015). Jacks of metal/metalloid chelation trade in plants-an overview. Frontier Plant Sciences, 6, 192. https://doi.org/10.3389/fpls.2015.00192

Arfan, M., Athar, H. R., \& Ashraf, M. (2007). Does exogenous application of salicylic acid through the rooting medium modulate growth and photosynthetic capacity in two differently adapted spring wheat cultivars under salt stress? Journal of Plant Physiology, 6, 685-694. https://doi.org/10.1016/j.jplph.2006.05.010

Awofolu, O. R. (2004). Impact of automobile exhaust on levels of lead in a commercial food from bus terminal. Journal of Applied Sciences and Environmental Management, 8, 23-27.

Aziz, M. A., Ghafoor, A., Saifullah, H. R. A., \& Sabir, M. (2007). Effect of glucose and acetic acid on Ni, Pb and $\mathrm{Zn}$ transformations in contaminated soil. Pakistan Journal of Agricultural Sciences, 44, 228-235.

Bazzaz, F. A., Carlson, R. W., \& Rolfe, G. L. (1975). The inhibition of corn and sunflower photosynthesis by lead. Physiologia Plantarum, 34, 326-329. https://doi.org/10.1111/j.1399-3054.1975.tb03847.x

Belaid, A., \& Morris, M. L. (1991). Wheat and Barley Production in Rainfed Marginal Environments of West Asia and North Africa. Problems and prospects (p. 91). CIMMYT Economics Working Paper. 
Bosch, S. M., Penuelas, J., \& Llusia, J. (2007). A deficiency in salicylic acid alters isoprenoid accumulation in water stressed transgenic Arabidopsis plants. Plant Sciences, 172, 756-762. https://doi.org/10.1016/ j.plantsci.2006.12.005

Capuana, M. (2011). Heavy metals and woody plants-biotechnologies for phytoremediation. Journal of Biogeosciences and Forestry, 4, 7-15. https://doi.org/10.3832/ifor0555-004

Castro, R., Caetano, L., Ferreira, G., Padilha, P., Saeki, M., Zara, L., ... Castro, G. (2011). Banana peel applied to the solid phase extraction of copper and lead from river water. Industrial and Engineering Chemistry and Reserach, 50, 3446-3451. https://doi.org/10.1021/ie101499e

Ceccarelli, S., Grando, S., \& Van Leur, J. (1987). Genetic diversity in barley landraces from Syria and Jordan. Euphytica, 36, 389-405. https://doi.org/10.1007/BF00041482

de Pascale, S., Maggio, A., Fogliano, V., Ambrosino, P., \& Ritieni, A. (2001). Irrigation with saline water improves carotenoids content and antioxidant activity of tomato. Horticultural and Science Biotechnology, 76, 447-453. https://doi.org/10.1080/14620316.2001.11511392

Delfine, S., Alvino, A., Villiani, M. C., \& Loreta, F. (1999). Restrictions to carbon dioxide conductance and photosynthesis in spinach leaves recovering from salt stress. Plant Physiology, 119, 1101-1106. https://doi.org/10.1104/pp.119.3.1101

Elwana, M. W. M., \& El-Hamahmyb, M. A. M. (2009). Improved productivity and quality associated with salicylic acid application in greenhouse pepper. Scientia Horticulturae, 122, 521-526. https://doi.org/10.1016/j.scienta.2009.07.001

Eun, S. O., Youn, H. S., \& Lee, Y. (2002). Lead disturbs microtubule organization in the root meristem of Zea mays. Physiologia Plantarum, 110, 357-365. https://doi.org/10.1111/j.1399-3054.2000.1100310.x

Fahr, M., Laplaze, L., Bendaou, N., Hocher, V., El Mzibri, M., Bogusz, D., \& Smouni, A. (2013). Effect of lead on root growth. Frontier Plant Sciences, 4, 175. https://doi.org/10.3389/fpls.2013.00175

Gisbert, C., Ros, R., Deharo, A., Walker, D. J., Pilarbernal, M., Serrano, R., \& Navarro-Avino, J. (2003). A plant genetically modified that accumulates $\mathrm{Pb}$ is especially promising for phytoremediation. Biochemistry and Biophysics Reserach Communication, 303, 440-445. https://doi.org/10.1016/S0006-291X(03)00349-8

Gunes, A., Inal, A., Alpaslan, M., Eraslan, F., Bagci, E. G., \& Cicek, N. (2007). Salicylic acid induced changes on some physiological parameters symptomatic for oxidative stress and mineral nutrition in maize (Zea mays L.) grown under salinity. Journal of Plant Physiology, 164, 728-736. https://doi.org/10.1016/ j.jplph.2005.12.009

Gupta, A. K., \& Sinha, S. (2007). Assessment of different single extraction methods for the prediction of bioavailable metals from tannery waste contaminated soil to Brassica juncea L. Czern. (var. aibhav). Journal of Hazardous Materials, 149, 144-150. https://doi.org/10.1016/j.jhazmat.2007.03.062

Hall, J. L. (2002). Cellular mechanisms for heavy metal detoxification and tolerance. Journal of Experimental Botany, 53, 1-11. https://doi.org/10.1093/jexbot/53.366.1

Hassanein, R. A., Hashem, H. A., El-Deep, M. H., \& Shouman, A. (2013). Soil contamination with heavy metals and its effect on growth, yield and physiological responses of vegetable crop plants (Turnip and Lettuce). Journal of Stress Physiology and Biochemistry, 9, 146-162.

Horvath, E., Szalai, G., \& Janda, T. (2007). Induction of Abiotic Stress Tolerance by Salicylic Acid Signaling. Journal of Plant Growth Regulation, 26, 290-300. https://doi.org/10.1007/s00344-007-9017-4

Huang, J. W., Grunes, D. L., \& Kochian, L. V. (1994). Voltage dependent $\mathrm{Ca}^{2+}$ influx into right-side-out plasmamembrane vesicles isolated from wheat roots: characteristics of a putative $\mathrm{Ca}^{2+}$ channel. Proceeding of National Academy of Sciences of the United State of America, 91, 3473-3477. https://doi.org/10.1073/ pnas.91.8.3473

Huchzermeyer, B., \& Koyro, H. W. (2005). Salt and drought stress effects on photosynthesis. In M. Pessarakli (Ed.), Handbook of plant and crop stress (2nd ed., pp. 751-778). Marcel Dekker Inc., New York, USA. https://doi.org/10.1201/9781420027877.ch39

Hussain, A., Abbas, N., Arshad, F., Akram, M., Khan, Z. I., Ahmad, K., Mirzael, F. (2013). Effects of diverse doses of Lead $(\mathrm{Pb})$ on different growth attributes of Zea mays L. Agriculture Science, 4, 262-265. 
Karlidag, H., Yildirim, E., \& Turan, M. (2009). Salicylic acid ameliorates the adverse effect of salt stress on strawberry. Scientia Agricola, 66, 271-278. https://doi.org/10.1590/S0103-90162009000200006

Khan, W., Prithiviraj, B., \& Smith, D. (2003). Photosynthetic response of corn and soybean to foliar application of salicylates. Journal of Plant Physiology, 160, 485-492. https://doi.org/10.1078/0176-1617-00865

Li, L., Xing, W., Scheckel, G., Xiang, G., Ji, H., \& Li, H. (2013). Lead retention in a calcareous soil influenced by calcium and phosphate amendments. Journal of Hazardous Materials, 15, 262-250. https://doi.org/ 10.1016/j.jhazmat.2013.08.058

Li, Q., Cai, S., Mo, C., Chu, B., Peng, L., \& Yang, F. (2010). Toxic effects of heavy metals and their accumulation in vegetables grown in a saline soil. Ecotoxicology and Environmental Safety, 73, 84-88. https://doi.org/10.1016/j.ecoenv.2009.09.002

Marashal, J., Corzo, A., Leigh, R. A., \& Sanders, D. (1994). Membrane potential-dependent calcium transport in right-side-out plasma membrane vesicles from Zea mays L. roots. The Plant Journal, 5, 683-694. https://doi.org/10.1111/j.1365-313X.1994.00683.x

Meers, E., Van Slycken, S., Adriaensen, K., Ruttens, A., Vangronsveld, J., Laing, D., ... Tack, T. F. (2010). The use of bio-energy crops (Zea mays) for 'phytoattenuation' of heavy metals on moderately contaminated soils: a field experiment. Chemosphere, 78, 35-41. https://doi.org/10.1016/j.chemosphere.2009.08.015

Metwally, A., Finkmemeier, I., Georgi, M., \& Dietz, K. J. (2003). Salicylic acid alleviates the Cd toxicity in barley seedlings. Plant Physiology, 132, 272-281. https://doi.org/10.1104/pp.102.018457

Monni, S., Uhlig, C., Junttila, O., Hansen, E., \& Hynynen, J. (2001). Chemical composition and ecophysiological responses of Empetrum nigrum to above ground element application. Environmental Pollution, 112, 417-426. https://doi.org/10.1016/S0269-7491(00)00139-1

Najafian, S., Khoshkhui, M., Tavallali, V., \& Saharkhiz, M. J. (2009). Effect of salicylic acid and salinity in thyme (Thymus vulgaris L.): Investigation on changes in gas exchange, water relations, and membrane stabilization and biomass accumulation. Australian Journal of Basic and Applied Sciences, 3, 2620-2626.

Paivoke, A. E. A. (2002). Soil lead alters phytase activity and mineral nutrient balance of Pisum sativum. Environmental and Experimental Botany, 48, 61-73. https://doi.org/10.1016/S0098-8472(02)00011-4

Prasad, D. D. K., \& Prasad, A. R. K. (1987). Altered $\alpha$-amino luvelinic acid metabolism by $\mathrm{Pb}$ and $\mathrm{Hg}$ in germinating seedling of Bajra (Pennisetum typhoidenum). Journal of Plant Physiology, 127, 241-249. https://doi.org/10.1016/S0176-1617(87)80143-8

Sengar, R. S., Gautam, M., Sengar, R. S., Garg, S. K., Sengar, K., \& Chaudary, R. (2008). Lead stress effect on physiobiochemical activities of higher plants. Rev. Environ. Contam. Toxicol., 196, 73-93. https://doi.org/10.1007/978-0-387-78444-1_3

Shakirova, F. M., Sakhabutdinova, A. R., Bezrukova, M. V., Fatkhutdinova, R. A., \& Fatkhutdinova, D. R. (2003). Changes in the hormonal status of wheat seedlings induced by salicylic acid and salinity. Plant Science, 164, 317-322. https://doi.org/10.1016/S0168-9452(02)00415-6

Sharma, P., \& Dubey, R. S. (2005). Lead toxicity in plants. Brazilian Journal of Plant Physiology, 17, 35-52. https://doi.org/10.1590/S1677-04202005000100004

Sharma, S. S., Dietz, K.-J., \& Mimura, T. (2016). Vacuolar compartmentalization as indispensable component of heavy metal detoxification in plants. Plant Cell and Environment, 39, 1112-1126. https://doi.org/10.1111/ pce. 12706

Simaei, M., Khavari-Nejad, R. A., \& Bernard, F. (2012). Exogenous application of salicylic acid and nitric oxide on the ionic contents and enzymatic activities in NaCl-stressed soybean plants. American Journal of Plant Sciences, 3, 1495-1503. https://doi.org/10.4236/ajps.2012.310180

Taiz, L., \& Zeiger, E. (2010). Plant physiology (5th ed.). Sinauer Associates Inc. Publishers, Sunderland.

Tangahu, B. V., Abdullah, S. R. S., Basri, H., Idris, M., Anuar, N., \& Mukhlisin, M. (2011). A review on heavy metals $(\mathrm{As}, \mathrm{Pb}$, and $\mathrm{Hg}$ ) uptake by plants through phytoremediation. International Journal of Chemical Engineering, 2011,31. https://doi.org/10.1155/2011/939161

Tomsig, J. L., \& Suszkiw, J. B. (1991). Permeation of Pb through calcium channels: fura-2 measurements of voltage and dihydropyridine sensitive $\mathrm{Pb}$ entry in isolated bovine chromaffin cells. Biochimica et Biophysica Acta, 1069, 197-200. https://doi.org/10.1016/0005-2736(91)90124-Q 
Vicente, M. R. S., \& Plasencia, J. (2011). Salicylic acid beyond defense: Its role in plant growth and development. Journal of Experimental Botany, 62, 3321-3338. https://doi.org/10.1093/jxb/err031

Wahid, A., Arshad, M., \& Farooq, M. (2009). Cadmium phytotoxicity: Responses, mechanisms and mitigation strategies. In E. Lichtfouse (Ed.), Advances in sustainable-book series (Vol. 1, pp. 371-403). Springer, New York. https://doi.org/10.1007/978-1-4020-9654-9_17

Yang, Y. Y., Jung, J. Y., Song, W. Y., Suh, H. S., \& Lee, Y. (2000). Identification of rice varieties with high tolerance or sensitivity to lead and characterization of the mechanism of tolerance. Plant Physiology, 124, 1019-1026. https://doi.org/10.1104/pp.124.3.1019

\section{Copyrights}

Copyright for this article is retained by the author(s), with first publication rights granted to the journal.

This is an open-access article distributed under the terms and conditions of the Creative Commons Attribution license (http://creativecommons.org/licenses/by/4.0/). 